\title{
Social movements and the politics of care: empathy, solidarity and eviction blockades
}

DOI:

10.1080/14742837.2019.1665504

\section{Document Version}

Accepted author manuscript

Link to publication record in Manchester Research Explorer

\section{Citation for published version (APA):}

Santos, F. G. (2019). Social movements and the politics of care: empathy, solidarity and eviction blockades. Social Movement Studies. https://doi.org/10.1080/14742837.2019.1665504

\section{Published in:}

Social Movement Studies

\section{Citing this paper}

Please note that where the full-text provided on Manchester Research Explorer is the Author Accepted Manuscript or Proof version this may differ from the final Published version. If citing, it is advised that you check and use the publisher's definitive version.

\section{General rights}

Copyright and moral rights for the publications made accessible in the Research Explorer are retained by the authors and/or other copyright owners and it is a condition of accessing publications that users recognise and abide by the legal requirements associated with these rights.

\section{Takedown policy}

If you believe that this document breaches copyright please refer to the University of Manchester's Takedown Procedures [http://man.ac.uk/04Y6Bo] or contact uml.scholarlycommunications@manchester.ac.uk providing relevant details, so we can investigate your claim.

\section{OPEN ACCESS}




\title{
Social Movements and the Politics of Care: Empathy, Solidarity and Eviction Blockades
}

\author{
Felipe G. Santos (University of Manchester \& Central European University)
}

Paper published at: Social Movement Studies

Link to article: http://dx.doi.org/10.1080/14742837.2019.1665504

\begin{abstract}
This paper develops a perspective of mobilization based on the ethics of care to explore the complexities of political solidarity in social movements. On the one hand, it is interested in the reasons why commonly aggrieved individuals do not always collaborate to confront their oppression. On the other, it explores why sometimes people initiate mobilization for causes that do not benefit them directly. From a care perspective, aggrieved individuals may not mobilize to confront their troubles because some of their caring needs (emotional, identity, and participatory) are not covered. At the same time, empathy motivates people not affected by a grievance to initiate mobilization in support of the oppressed collective. Internal solidarity among those aggrieved may be created during the process of mobilization through care work. The analytical relevance of this model is demonstrated explaining the mobilization of the 'Platform of Those Affected by Mortgages', the biggest housing organization in Spain. A care-based approach to mobilization contributes to our analysis of contentious collective action by helping to better understand the complexities of political solidarity and the mechanisms through which organizations foster solidarity among their members.]
\end{abstract}

Keywords: [care, empathy, solidarity, evictions, Plataforma de Afectados por la Hipoteca, PAH]

Correspondence address: [Politics Department, School of Social Sciences, Arthur Lewis Building, University of Manchester, Oxford Road, Manchester M13 9PL / f.santos@manchester.ac.uk]

\section{Notes on contributors}

Felipe G. Santos is Research Associate at the University of Manchester and $\mathrm{PhD}$ Researcher at the Central European University.

\section{Author links}

Felipe G. Santos ORCiD ID: https://orcid.org/0000-0001-7006-2088 
Acknowledgements: [This paper has benefited from extensive feedback at different stages of its development. The author would like to thank Béla Greskovits, Austin Choi-Fitzpatrick, Erin Jenne, David S. Meyer, Jeff Goodwin, Kerman Calvo, Anna Domaradzka, Felix Bender, and Robin Bellers for their insightful comments. Different versions of the paper were presented at the conference Spain: Social Movements Between Past and Present at the University of Cambridge, the seminar of the Center for the Study of Democracy at the University of California Irvine, and the Graduate Conference of the Central European University. The author would like to thank the participants of these events for their engaged discussions. Finally, big thanks to the editors of Social Movement Studies and the two anonymous reviewers for their constructive feedback throughout the publication process.] 
Home foreclosures are one of the most dramatic sides of financial capitalism and were at the center of the crisis that originated in 2008. Only in Spain, 370,000 evictions were executed between 2007 and 2017, according to the Spanish General Council of the Judiciary (Consejo General del Poder Judicial, 2019). The Platform of Those Affected by Mortgages (PAH, by its Spanish acronym ${ }^{1}$ ) was created to confront this drama. To this date, the PAH has blocked more than 4,000 evictions through civil resistance (Plataforma de Afectados por la Hipoteca, 2019) and prevented many more through popular pressure and negotiations with banks. Despite its success, the PAH faced serious challenges to build solidarity among those in risk of eviction. People facing home foreclosures prioritized looking for individualized solutions over collective action. This raises the question why solidarity did not spark, despite those facing eviction having a shared grievance and a common adversary. Conversely, solidarity appeared among people who were not affected by this issue. None of the six people generally identified as the PAH's founders (Blanchar, 2014) had a mortgage. How can we explain that people not affected by the problem of evictions took the initiative to address this issue through contentious collective action?

This article makes two contributions. First, it provides a framework to explain why a group initiates mobilization to defend the rights of others. I present a four-step process through which empathy motivates external solidarity and contentious mobilization. I coin the term conscience entrepreneurs to refer to those individuals and groups who initiate a social movement organization (SMO) but will not benefit directly from the accomplishment of its goals. Second, it explains how SMOs create solidarity among those affected by the same grievance. Early risers create solidarity among those facing oppression through what I call care work. Social movements and their members engage in care work when they aim at creating, sustaining and repairing social relations, as well as fulfilling the needs of their 
members and other groups. I identify three types of care work: emotional, identity, and participatory and explain how they contribute to strengthening internal solidarity.

The paper is structured as follows. First, I discuss why self-interested solidarity does not often appear among commonly aggrieved individuals. Second, I explore what leads people to mobilize for the rights of others. Third, I develop a model that explains how empathic solidarity triggers contentious collective action and how activists create internal solidarity. Then, I use this model to explain how the PAH managed to block its first eviction. I conclude by discussing the opportunities that this new framework opens for the study of social movements.

\section{The Complexities of Solidarity in Contentious Collective Action}

Scholars have long debated the role and impact of solidarity in contentious collective action. Solidarity is a key factor for the development of collective identities, commitment to the group, and mobilization more generally (Fireman \& Gamson, 1979; Hunt \& Benford, 2004). For Melucci, solidarity is 'the ability of actors to recognize others, and to be recognized, as belonging to the same social unit' (1996, p. 23). However, in this paper I follow a Durkheimian approach (cf. Durkheim, 1987 [1897]; Hechter, 1987), and define solidarity as the willingness of actors to contribute private resources - time, money, and energy - to the collective ends of a group. Melucci emphasizes recognition and the Durkheimian definition is centered on individuals' contributions of resources. While recognition does not necessarily translate into any observable behavior and may lead to confusions between solidarity and collective identities, focusing on actual contributions facilitates mapping the mechanisms through which solidarity leads to contentious collective action. 
Depending on whether one contributes towards a cause from which one can benefit or not, Hunt and Benford (2004) differentiate between internal and external solidarity. Internal solidarity takes place in relation to a group to which one belongs, while external solidarity is directed towards an external collective. Consequently, internal solidarity is motivated, at least in part, by self-interest, as the achievement of the collective aim is expected to result in a bettering of one's position. External solidarity requires empathy, as one needs to relate to the position of the aggrieved group before contributing one's private resources to their cause. Although attention to external solidarity is not new, non-beneficiary constituents have generally been approached as followers to mobilizations that are already ongoing (McCarthy \& Zald, 1977; Messner, Greenberg, \& Peretz, 2015) and whose contributions are based on 'money' rather than 'time' (Della Porta \& Diani, 2006). Some exceptions are studies focused on movements of the religious left (e.g. Nepstad, 2004, 2008; Russo, 2018), refugee solidarity groups (e.g. Della Porta, 2018), and animal rights collectives (e.g. Jasper \& Poulsen, 1995; Munro, 2005). However, we still need to unpack the dynamics of non-beneficiary participation in contentious collective action and explore why nonaggrieved individuals initiate mobilization.

\section{Apathetic against Oppression? Missing Solidarity among Aggrieved Collectives}

Grievances are generally understood as a necessary condition for the appearance of social movements (Klandermans, Roefs, \& Olivier, 2001; van Stekelenburg \& Klandermans, 2013) but are often associated with features that discourage solidarity. Grievances may produce 'avoidance emotions' (Klandermans, van der Toorn, \& van Stekelenburg, 2008, p. 995), which discourage interaction with others. For instance, many mothers experiencing postpartum depression were ashamed because they did not meet societal expectations associated with motherhood and avoided going public about their grievance (Taylor, 1996). Additionally, members of communities that are socially stigmatized 
experience hopelessness, low self-esteem and demoralization (Link, 1987), which discourage participation in social movements (Gecas, 2000). For example, the AIDS Coalition to Unleash Power (ACT UP) had to confront the stigma and spoiled identities prevalent among American LGBTI communities in the 80 's before it mobilized them against the AIDS epidemic that was killing many of them (Gould, 2009). Individuals experiencing avoidance emotions or who identify with socially stigmatized groups need to pass through a healing phase, where some of these emotional and identity concerns are addressed, before they engage in solidarity activities such as contentious collective action. Social movements provide 'free spaces' (Evans \& Boyte, 1986; Polletta, 1999) where these interactions may take place.

\section{When Empathy is Stronger than Self-Interest: Origins of Solidarity towards an Outgroup}

People may act for the benefit of others for three reasons. First, from a rationalist perspective, external solidarity may originate from the immaterial benefits (e.g. self-esteem and personal connections) individuals expect from their involvement or from 'selective incentives' (Olson, 1965). Selective incentives are rewards and punishments that are not directly related to involvement in a movement but depend on whether the person took part in it. Second, from a structuralist viewpoint, empathic solidarity may originate from the characteristics of the sociopolitical environment. The availability of resources (Jenkins, 1983; McCarthy \& Zald, 1977), political opportunities (McAdam, 1999 [1982]; Meyer, 2004), and personal networks (Diani \& McAdam, 2003) may encourage individuals to act collectively for a cause from which they will not benefit directly but that gives them higher chances of success. Finally, from a culturalist position, solidarity towards an outgroup may originate from values, identities, and processes of socialization. On the individual level, activists develop morals that lead them to place importance on defending the rights of others (Vecchione et al., 2015). Religious motivations may also 
encourage believers' mobilization to alleviate others' suffering (Nepstad, 2004; Russo, 2018). Further, non-beneficiary mobilization may be motivated by a 'moral shock' (Jasper \& Poulsen, 1995). From a societal perspective, economic security changes the values of a community, which starts giving more importance to immaterial issues (Inglehart, 1977). These changes have affected the topics around which groups who enjoy a certain economic status mobilize (Kriesi, Koopmans, Duyvendak, \& Giugni, 1995; Melucci, Keane, \& Mier, 1989). Because of similar reasons, people whose material needs are covered may act to improve the status of those who do not share their prosperity.

\section{Care and Social Movements: A New Framework for Analysis}

Gilligan (1982) and Noddings (1986) put forward the ethics of care as a critique to what they call the justice perspective, associated with Kantian and utilitarian ethics. While the ethics of care originated in social psychology to explain different moral developments between women and men (Gilligan, 1982), later scholarship expanded its scope to political theory (Held, 2006; Tronto, 1993, 2013), medical (Tong, 1998) and business (Simola, 2003) ethics, and international relations (Robinson, 2011). The ethics of care have received little attention in social movement studies, even if some scholars have already pointed at the importance of empowering individuals through relationships in the expanded private sphere, noticing the role of women in developing these morecaring logics of action (Neuhouser, 1995; Stall \& Stoecker, 1998).

Care is 'a species activity that includes everything that we do to maintain, continue, and repair our "world" so that we can live in it as well as possible. That world includes our bodies, our selves, and our environment' (Tronto, 2013, p. 19). It consists on protecting our selves and others from 'extraordinary incursions of violence or other forms of disruption into our daily lives' (Tronto, 
1993, p. 104) and requires a 'sensitivity for the needs of others' (Gilligan, 1982, p. 16). Moreover, care is generally a relational action that goes beyond the mere act of thinking, as this sensitivity must result in taking responsibility to address the identified needs (Held, 2006). Tronto (1993, 2013) provides a four-step process of how humans care, which I use to theorize contentious mobilization that originates from empathic solidarity.

(1) Caring about: The root of care-based mobilization is the empathy of a group towards the need of another collective. I call the initiators of this type of mobilization conscience entrepreneurs, to differentiate them from beneficiary social movement entrepreneurs. Conscience entrepreneurs are movement entrepreneurs who will not benefit directly from achieving the movement's goals. Conscience entrepreneurs need to place themselves in the position of an external group and understand its perspective.

(2) Caring for: After the detection of the need, the next step is to assume responsibility to address it. In the context of a social movement, this requires the recognition that the roots of the unmet needs are political, and that collective action is needed to address them. This is the moment when conscience entrepreneurs decide to start organizing.

(3) Care giving: The next step is to address the identified caring needs. This is when collective action begins. This process is iterative. More needs may be detected after initiating mobilization, starting a new caring process. This may happen either because certain strategies are unsuccessful or because once some needs are covered, new ones appear. Furthermore, different care giving processes may take place at the same time, as different subgroups of the collective may have diverse needs. Care giving does not take place exclusively through non-contentious actions. For example, an eviction blockade or a 
protest against the mistreatment of refugees are also guided by the logic of addressing the needs of a person or collective.

(4) Care receiving: Once care relationships take place, there needs to be a reaction to them. The response can simply be the acknowledgment that care has, or has not, been successful. Whether the person or group that has received care eventually takes ownership of their struggle is what determines the sometimes-thin difference between transformative contentious political action and assistance-based collective activities.

Once empathic solidarity has sparked collective action, early risers can engage in activities that promote internal solidarity. Through the activities and interactions that take place during the process of mobilization, some of the constraints that prevented self-interested solidarity can be addressed. Care work may take different forms and, as I develop in the analytical sections, in the PAH they can be categorized in three ways:

Emotional care takes place through interactions among activists that foster 'approach emotions' (Klandermans et al., 2008), which facilitate mobilization. This 'emotion work' may take place through 'intimate social networks' (Goodwin \& Pfaff, 2003, p. 287) that provide encouragement and moral support, or through rituals where certain emotions are cherished and shared by their participants (Collins, 2004). These performances generate high emotional energy, 'a feeling of confidence and enthusiasm for social interaction' (Collins, 2004, p. 108), which fosters solidarity among members. The long-term objective of emotional care is to eliminate avoidance emotions, which hamper mobilization, and to promote approach emotions to foster internal solidarity and engagement in the movement's activities. 
Identity care consists of the organizational dynamics and the relationships among members that affect their identities. First, it refers to the development of a positive 'self-concept' (Gecas, 1982, 1986, 1991). Borrowing from Gecas, I suggest three components of self-concept care. First, it consists of improving members' self-esteem. Second, it aims at encouraging individuals to see themselves as competent and efficacious. This is particularly important for groups that were socialized as passive subjects through social shaming or dependence on social services and charity. Third, it seeks to encourage members to experience themselves as authentic and meaningful, which frequently happens through the appreciation that they receive for their contributions to the group. Having a better perception of oneself, as well as feeling efficacious and authentic encourages individuals to contribute their private resources to address collective grievances. Another component of identity care is communal care, which consists of providing members with a community that shares similar values and where participants identify as peers. The outcome of this process is what authors have referred to as a collective identity, something that fosters solidarity among group members (Hunt \& Benford, 2004). Communal care fosters contributions aimed at achieving collective ends, instead of individualized objectives.

Participatory care refers to efforts aimed at reducing the constraints that complicate participation in the activities of the group. Organizations may coordinate some of the personal obligations of members, so they can dedicate more time to the activities of the movement. For instance, the Black Panthers' free breakfast program was a milestone in the self-organization of black communities and facilitated the organization of the civil-rights movement (Churchill, 2001). Additionally, organizations can reduce the costs and risks associated with participating in an action. Some examples are coordinating buses to travel to a demonstration organized far away, and playing music during marches to make them more enjoyable and seem less confrontational. 
Participatory care consists also in providing members with the knowledge and skills to participate in the movement's activities. Training can range from explaining legislation in an accessible way to workshops on civil resistance.

Although care can be divided into types for analytical purposes, it is a holistic process. The boundaries between categories are often unclear and different processes of care interact, reinforcing each other. Emotional care contributes to the development of collective identities and to changes in activists' self-concepts; collective identities foster solidarity with newcomers and facilitate unconscious interactions of emotional caring; when childcare is arranged within the assembly or the movement coordinates a bus to attend a demonstration, collective identities are reinforced; and the identification of an experienced member with a newcomer of her organization encourages greater attention to this person during a training where several groups participate. Despite the blurriness of the boundaries between types in real-world settings, the analytical separation proposed here is still useful because it helps to identify the distinct needs that hamper solidarity and map the specific organizational strategies to address them.

\section{Methodology}

This research and its preparation involved qualitative text analysis of articles from four newspapers for the period 2009-2016, one year of engaged participant observation and 71 semi-structured interviews. The politics of care framework has been borrowed from Tronto $(1993,2013)$ and applied to the data gathered. The three categories of care work have been constructed inductively. They originate from the patterns noticed during fieldwork and, later on, they have been connected with the academic literature to develop the typology.

The collection of primary data took place between June 2017 and June 2018, eight years after the PAH was created. The distance from some of the events discussed presents both 
opportunities and challenges. On the one hand, eight years are enough time for care practices to influence those that experienced them. Through life-interviews, it was possible to explore the evolution of more experienced members since they joined the PAH. Besides, new people arrived at the PAH's assemblies practically every week, so it was possible to compare the recollections of veteran members with the observations of newcomers' behavior and their evolution. On the other hand, founders' memories about the origins of the organization may have been distorted during these years. To assure consistence in their stories, data was triangulated, comparing the responses from different interviewees among themselves, as well as with the results of the newspaper analysis of El País, El Mundo, ABC, and El Periódico de Catalunya. The first two outlets are newspapers that are associated with the Spanish center-left and center-right, respectively. $A B C$ is a conservative national outlet that was selected to include a priori critical views in the analysis. Finally, El Periódico de Catalunya is a Catalonian regional newspaper, which covered the organization since its creation in Barcelona. Pieces of news were gathered through LexisNexis using the keywords 'PAH' and 'Plataforma de Afectados por la Hipoteca', and the period covered was 2009-2016. This search resulted in 2.101 articles.

Contact with the organization was made through common acquaintances with some members. After two weeks observing the dynamics of the organization in Barcelona and the structure of its meetings, I introduced myself during an assembly and I was mindful to disclose my role of researcher during my exchanges with members. Hence, I expect that most members with whom I shared participation were aware of my position. During the period of study, I participated in PAH Barcelona's collective counseling and coordination weekly assemblies, several eviction blockades each week, tens of bank protests, seven accompaniments to talk to local administrations, six accompaniments to negotiate with bank clerks, and the occupation of a building to rehouse 
evicted members. Additionally, in March 2018, I went to the European Parliament with members from different locations in Spain in a two-days trip organized to gather international support to a bill they presented at the Spanish Parliament.

The first respondents for the interviews were selected based on the newspaper analysis. Subsequent people were approached through my interactions with them during the engaged participant observation and snowballing. The final sample included activists from Barcelona (29), Madrid (8), Sabadell (5), Terrassa (4), Valencia (4), Manresa (2), Seville (3), Blanes (2), Murcia (2), Pontevedra (2), Bilbao (2), Pamplona (1), Segovia (1), and members of Obra Social Barcelona (6), which was created after a split from the PAH Barcelona due to disagreements about strategy and some internal decision-making mechanisms. From these people, 17 were non-beneficiary constituents, including four of the six founders, and 54 were beneficiary activists.

\section{The Platform of Those Affected by Mortgages: Caring for Housing Rights}

The Platform of Those Affected by Mortgages was created in February 2009, when the Spanish housing bubble started to burst. During the bubble, many families took on loans to become homeowners, as rent prices were high and access to mortgages easy. There was also a general discourse among Spanish media and public opinion encouraging people to buy a house as a sound investment because 'housing prices never decrease' (Televisión Española, 2004). Even if at some point one was unable to meet one's mortgage payments, selling the property at a higher price was expected to be enough to repay the debt and make a profit. Already before the housing bubble burst, the construction sector started to stagnate. Many newly unemployed defaulted on their mortgages and when they tried to sell their houses, they found no buyers. Financial institutions started foreclosure procedures and, in the common case that nobody was found to buy the property, 
banks acquired it for $60 \%$ of its current tax value and evicted the previous owner. As the deed in lieu of foreclosure is not common in Spain, those evicted remained indebted for the difference between their mortgage debt plus interests and court fees, and the value paid by the bank.

Ten years after its creation, the PAH has had substantial impact. Currently, it is present in 254 locations throughout Spain. They have prevented more than 4,000 evictions (Plataforma de Afectados por la Hipoteca, 2019) and housed more than 2,500 people in occupied apartments owned by banks and vulture funds (García-Lamarca, 2017b; Plataforma de Afectados por la Hipoteca, 2016). Moreover, they gathered almost 1.5 million signatures in what became the biggest petition in Spanish history (Plataforma de Afectados por la Hipoteca, 2013). They have also contributed to reframing the discourses about the financial crisis and improved perceptions of occupation (Martinez, 2018). Finally, many of its members are now elected representatives, the most iconic of whom, Ada Colau, was the PAH's spokesperson and became mayor of Barcelona in 2015 .

\section{Caring About: When Empathy Inspires Housing Rights for Everyone}

the PAH was created by six conscience entrepreneurs, people who did not have a mortgage but whose empathic solidarity led them to explore ways to organize those who face eviction. Their personal stories show how empathy can originate from different sources. Four of them - Ada Colau, Adrià Alemany, Ernest Marco and Guillem Domingo - had previous activism experiences, so they were socialized into placing themselves in the position of others and taking responsibility to address the needs of an external collective. Ada and Adrià were members of $V$ de Vivienda, an organization focused on youth precarity and its problems to access housing, which was one of the first actors denouncing the bubble (Aguilar Fernández \& Fernández Gibaja, 2010). Additionally, Ernest and Guillem participated at the Ateneu Candela, a social center in Terrassa that aimed at 
engaging people beyond the traditional leftist circles. One of the initiatives of the center were the Offices for Social Rights, a space for collective counseling and support against precarity, be it at the work place, related to access to housing or the living conditions of undocumented migrants. At a certain point, they realized that discussions began to be mostly about mortgages and evictions. Seeing this situation, Ernest and Guillem started to explore ways to confront this emerging problem.

Even if $V$ de Vivienda is commonly cited as the origin of the PAH (Di Feliciantonio, 2017; Flesher Fominaya, 2015; Romanos, 2014), acknowledging the Offices for Social Rights is of crucial importance to understand the PAH's development. The PAH's collective counseling assemblies were inspired by the success of the assemblies of the Offices for Social Rights. Below, I discuss the centrality of collective counseling assemblies for the PAH's activity but, for now, a quote from a leader of PAH Barcelona summarizes it well 'if the coordination assembly is the PAH's brain, where we coordinate all our activities, the assemblies of collective counseling are its heart' (Non-beneficiary member 5, on 12 July 2018, Barcelona) ${ }^{2}$.

Ada and Ernest knew each other from their involvement with the alter-globalization movement and, given their converging analysis about the upcoming drama of evictions, they united efforts and started to reach out to their activist networks, but they had little success. Most progressive activists are renters, so they were not familiar with the topic. Moreover, activists considered that those who became indebted to buy a house contributed to the housing bubble.

There was the sensation that homeowners also created the housing bubble, that they were investing in housing, they were speculating with it. It was a group that was quite stigmatized. You could support renters, but supporting homeowners was not well regarded. (Founder 3, on 15 August 2017, Barcelona).

Most activists did not empathize with evicted homeowners and were not willing to contribute their private resources to the collective ends of this group. Differently from the PAH's founders, besides 
having no self-interest in the struggle, the rest of the activists felt no empathy towards indebted homeowners, so solidarity did not appear.

The other two founders - Lucía Delgado and Lucía Martín - had not been involved in social movements before. Their empathy originated in their discussions with Ernest, who was their coworker at the Autonomous University of Barcelona. Through the experiences they heard from him, they started to empathize with the struggles of people trapped in their mortgages.

Ernest spoke a lot about mortgages.

- 'You are also affected by the mortgage problem, we all are'.

- 'But I don't have a mortgage. How can I be affected?

Then, we would speak about the subprime crisis, about how many people were homeowners and how they were being evicted. I didn't have much time because during that period I played lots of basketball and I did not move in the social movement circles. I followed the news and had an opinion, but I did not participate in anything beyond having attended a couple of demonstrations. However, those stories were so horrible that I went to one of the meetings [preparing the creation of the PAH], and to the next one, and the next one... and I got hooked. (Founder 4, 23 August 2017, Barcelona).

Placing the stories of these six founders in a theoretical context, none of them had a mortgage and the issue around which they mobilized was not well regarded among their circles, making it difficult to explain their involvement through rationalist arguments. From the perspective of their personal resources, some of them were 'biographically unavailable' (McAdam, 1986), as other activities occupied their time, so their involvement cannot be understood from this stand. Moreover, political opportunities were rather closed. Between 1996 and 2012, there was a consensus among the Socialist and Conservative parties about the need for further liberalization of the housing market (Campos Echeverría, 2008). The support for the PAH's motions oscillated between $2 \%$ and $7 \%$ of the Parliament. ${ }^{3}$

From a care perspective, these six conscience entrepreneurs mobilized because, after being aware of the situation of those struggling to pay their mortgages, they empathized with them and 
felt responsible to address their need. Their empathy originated in cultural and structural factors. Ada, Adrià, Ernest and Guillem had developed ideologies and greater attentiveness to the situation of less-privileged groups through their previous activist involvements.

They started explaining [during the meetings of the Office for Social Rights] that they stopped paying, that they lost their apartment and that, on top of that, they had a debt that would stay with them the rest of their lives. This was a shock - what do you mean that you have been expulsed and you still have a debt? - And then we started thinking what could be done because this situation was unbearable. (Founder 3, on 15 August 2017, Barcelona).

Both Lucías were exposed to the information about the situation of those trapped in their mortgages through their networks and this knowledge made them more empathic to the struggles of those facing evictions and financial distress.

You listen to some of those stories and you realize that you could have been there too. I did not even consider getting a mortgage because my job was just too precarious, but what if I had been more stable? Then I would have probably gotten indebted too. (Founder 1, 22 June 2017, Barcelona).

The relative economic security of all founders facilitated their empathy, as they could afford thinking about other people's grievances. However, this is not a sufficient explanation, as many activists that were contacted by them did not want to mobilize for this cause despite their stable jobs.

\section{Caring For: Reaching Out to the Housing Activist Circles}

After the PAH's conscience entrepreneurs became acquainted with the problem of mortgages and evictions, they decided to reach out to those affected. They printed posters inviting people facing problems paying their mortgages to a meeting and stuck them around Barcelona. More than 100 people gathered at the assembly. Nevertheless, according to several interviews (Founder 1, 2, 3 and non-beneficiary member 10), they did not come with the intention of contributing their private resources to a collective end. Instead, they looked for individual answers such as how to best 
approach negotiations with their bank, and what kind of support was given by public administrations and charities.

Given the social importance attributed to homeownership in Spain, people trapped in their mortgages viewed their situation as a personal failure and identifying oneself with categories such as 'defaulter' or 'evicted' was extremely stigmatizing (Di Feliciantonio, 2017).

Owning a house was a social objective [...] Suddenly, the crisis comes, and you lose your job, you don't get any more gigs. You lose everything and you find that you are broke, and it is tough to admit it in public. It is tough because you feel ashamed, because it's a personal failure, because you don't want others to know that they are confiscating your stuff, that you cannot afford to pay for your home, that you don't have enough to fill the fridge. (Beneficiary member 36, 8 April 2018, Seville - online interview -).

Saying that those trapped in their mortgage experienced avoidance emotions seems to fall short in describing their reality. Many faced serious psychological issues (Vásquez-Vera et al., 2016, 2019) and others committed suicide. ${ }^{4}$ These cultural and emotional factors led them to attempts to solve their problem through individual actions. Many negotiated the refinancing of their debts with the bank. Others prioritized paying their mortgages over their dietary needs or relied on charity to cover them. The grievance they faced came together with other factors that complicated the appearance of self-interested solidarity.

From the reflections that many leaders shared during my interviews, they now understand that care work was crucial for self-interested solidarity to arise. The emotional, identity and participatory needs of their activists' base had to be addressed before those facing evictions would be willing to contribute to the collective. However, this conclusion came after long discussions about strategy, together with a process of trial and error.

\section{Care Giving: Addressing Members’ Needs before Contentious Mobilization}


Seeing the success of the first assembly, gatherings were organized every week. As people started to attend regularly, the founders decided to organize a demonstration. When the day of the march came, only around 40 people gathered, most of them activists who were not directly affected by the problem of mortgages. This experience made founders realize that people trapped in their mortgages faced barriers that prevented their internal solidarity and that they needed to be addressed before those trapped in their mortgages could engage in contentious collective activities.

We organized a demo and nobody came. We gathered around 40 people and we decided to walk on the sidewalk because we were ashamed to block the street with such a small crowd. [...] And we were all buddies. Maybe there were 2 affected persons only. We were really mad - How is it possible that nobody came? - But how are they going to come if they are devastated? What kind of demo would it be with everybody depressed all around? And then we realized that we needed to generate other dynamics to empower people. (Founder 1, 22 June 2017, Barcelona).

Self-interested solidarity was hampered by three unmet needs. First, those facing eviction were not emotionally prepared because they were ashamed of their situation. Second, they did not see a collective purpose to struggle for and they were socialized as passive subjects, receivers of help from administrations and charities. Third, they were not comfortable participating in a demonstration, as many had never been involved in contentious politics before. Those trapped in their mortgages did not participate in the rally because they were facing emotional, identity and participatory barriers that they needed to overcome before they would be ready to join a public and collective action.

The aftermath of the demonstration illustrates well how self-interested solidarity is constructed within SMOs. The PAH founders focused on two activities: collective counseling assemblies and accompaniments. Collective counseling consists of assemblies where whoever has a question exposes her situation and doubts, and the rest of the people give advice based on their own experience. An important feature of these assemblies is that counseling is expected to come from other members (Di Feliciantonio, 2017; García-Lamarca, 2017a). The PAH's collective 
counseling assemblies have an important component of participatory care. They facilitate the contribution of private resources to the group, as the cost of contributing is low, since it consists of sharing one's experiences. These seemingly small contributions have a great impact on the advancement of the organizational aims as members learn best practices and are better able to confront financial institutions. At the beginning nobody knew much about the process but, through studying the mortgage laws and translating them from legal jargon to everyday language, sharing experiences and best practices, and trial and error, the PAH managed to develop substantial collective knowledge and dynamics through which members can support each other. In other words, collective counseling facilitated the beginnings of self-interested solidarity.

The horizontal dynamics of collective counseling assemblies contribute to communal care and the development of collective identities. Support comes directly from one's peers, something that created strong bonds among members. There are also constant references to the acceptance of the person in the group and the better chances to achieve a solution through it. When newcomers share their story at the assembly, the most common reaction is somebody saying, 'don't worry, now you are with the PAH and you are no longer alone'. Moreover, members make constant references to the PAH being their family. For instance, the main Telegram chat of PAH Barcelona, the main channel of communication for last-minute updates in which all members participate, is called 'PAHmilia', a combination of the words PAH and family. This feeling of acceptance by the group and the hope that comes with it encourages the involvement of the person in the movement's activities and the development of internal solidarity.

Accompaniments consist of gathering a group of activists to go together with a person to a meeting with banks or the administration and exemplify well how self-concept and communal care work in the PAH. Even if the affected member is the one expected to lead the negotiation, if she 
finds difficulties during the meeting, some other person may speak on her behalf. Affected members can better confront their fear and anxiety because they know that there are other activists ready to intervene if they need it. Moreover, bank clerks are willing to make more compromises to avoid a protest in their bank office if the negotiations do not progress. This new context increases members' perceived and actual self-efficacy. While prior to joining the PAH, members engaged with bank clerks alone and mostly without success, now they can increase their demands and still achieve what they wish.

When you go by yourself, they don't care about you but when you go with the PAH, they do. Before they always say no, but when you go with other people there are things that become possible. In fact, this afternoon I'm going to an accompaniment with somebody that doesn't want to go with her kids to a public hostel, because that is not a dignified housing for children. We are going to tell the administration that, if they don't give her access to public housing, they will have to face the whole PAH. (Beneficiary member 47, 26 May 2018, Pontevedra - online interview -).

Accompaniments contribute to communal care creating strong bonds among members. Many activists remember those who were present during their first accompaniment, even after several years. Moreover, the PAH's constant use of the idiom hoy por ti y mañana por mí (I'll scratch your back and you scratch mine) encourages participants to understand their fight as a collective struggle where they are expected to do the same for other members. The idiom is commonly used when some member thanks others for their help, but it is also reminded when asking for participation in some activity. This double use of this expression emphasizes that the PAH's strength resides in members' reciprocity. Individual triumphs are collective victories achieved through the solidary engagement of others. These dynamics and framing of caring for each other facilitate internal solidarity.

In addition to improving members' capacity to pressure their banks, collective counseling assemblies and accompaniments provide spaces for care work. Through these activities, the PAH addresses the emotional, identity and participatory needs of its members and constructs internal 
solidarity. As I explain in the next section, these interactions were crucial to prepare activists for their participation in the PAH's first eviction blockade.

\section{Care Receiving: Contentious Collective Action as a Response to Care}

Despite the efforts of the PAH and its members when negotiating with banks to avoid being evicted, frequently no compromise is achieved. During most of my interviews with the PAH's founders, it was clear that they wanted to block evictions on the street from the beginning. However, it took them one and a half years of care work to build enough empowerment and solidarity to organize their first eviction blockade, in November 2010.

People did not want to confront evictions [on the street]. They would rather give their flat up and go somewhere else. So, we did not want to push it, but we were constantly looking for somebody who wanted to confront, somebody who wanted to block the eviction. (Non-beneficiary member 10, 4 September 2017, Terrassa).

Emotional and identity needs were two of the reasons that prevented people facing foreclosure procedures to participate in eviction blockades. A number of interviewees who were facing eviction from their homes in Barcelona during the PAH's early years reported feelings of shame or embarrassment at how their neighbors might see their situation (Beneficiary members 4, 15, 17, 28 , and 47). Other members were not comfortable making their housing depend on strangers. Their lack of identification with other members and the collective hindered their trust on the willingness of their peers to contribute their individual resources to protect their home through civil resistance.

When I arrived at the PAH, I was still paying my mortgage, even if I knew that I wouldn't be able to pay for much longer. Everyone told me that, if I knew that I would have to default soon, it was best to stop paying already [...] I kept paying for another couple of months, mostly because I did not want to receive calls from the bank during Christmas, but also because I didn't know those people. So, I was not going to do whatever they told me just like that. (Beneficiary member 19, 31 July 2017, Barcelona).

These factors may help explain an unwillingness to join an action of civil resistance on the streets and a preference for leaving quietly. 
The solidarity constructed during collective counseling assemblies and accompaniments was key to overcoming these problems. The relationships that appear though involvement in these spaces foster interactions of communal care that contribute to the appearance of internal solidarity. When members care for each other and see instances of commitment to the collective, they are more comfortable trusting that their peers will contribute their private resources to defending one's right to housing. The reverse is also true, when members share spaces of care within the organization, they develop bonds that encourage them to engage in risky activities to protect each other from harm.

It is not the same going to the eviction blockade for whoever because you are asked to go than going to the one of Pepita, with whom you have been in the PAH for a year. You have developed affective bonds. You have realized that you are in the same boat. You have even spent time with her outside of the PAH. So, when they are going to kick her out, you go there, not because of activism but because she is important to you. (Non-beneficiary member 10, 4 September 2017, Terrassa).

For the first eviction blockade, emotional care was instrumental in providing the person affected with the necessary courage to engage in civil disobedience. Prior to the eviction blockade, leaders had several exchanges with this member until he felt ready for the confrontation.

The first STOP Evictions was the one for Luis from La Bisbal del Penadés, who said - yes, I am ready to go public, let's call for the STOP Evictions - but previously we made a process in which we talked to him so he would have the determination of saying - yes, I am going to face the music in front of my family, in front of my acquaintances, in front of the whole world... I will be on TV, I don't care, I am going to denounce this situation. (Founder 2, 12 August 2017, Barcelona).

Participatory care was also crucial for the PAH members, particularly those with no previous activism involvements, to be comfortable in their first experience of civil resistance. Everything was organized so everyone would know what to do and expect, reducing the actual and perceived risks of the action. There were those in charge to speak to the police and the judicial entourage, those recording videos both to publicize the action and to discourage police violence, and there were trainings on how to react to different scenarios. Also, to make the action seem less confrontational, banners were shaped as comic bubbles. ${ }^{5}$ All these preparations were aimed at 
removing the barriers that would prevent people from contributing their private resources to the collective end of the eviction blockade.

Finally, some 50 people gathered in front of Luis' house. This came as a surprise both for the judicial entourage and the police, who postponed the date for one month. This episode was the beginning of the normalization of eviction blockades through civil disobedience. Of the 54 beneficiary constituents I interviewed, 43 (79.6\%) indicated little prior experience of activism. However, through their participation in the STOP Evictions campaign, they began to see civil resistance as 'a normal practice and as a moral obligation, as a collective tool to transform reality, and a legitimate action applicable to other struggles' (Mir García, França, Macías Caparrós, \& Veciana, 2013, p. 58 author's translation).

Based on this analysis, it is possible to identify three responses to care. First, the appearance of solidarity among those facing evictions. Second, the PAH could engage in contentious collective action and eviction blockades became part of its repertoire. Finally, it changed the PAH members' approach to political action, as they started to see civil resistance as a normal practice, also beyond their organizational involvement.

\section{Conclusion}

This article has sought to expand our understanding of the origins of solidarity in contentious collective action. It has presented a framework to study social movements from the perspective of the Ethics of Care. Care has been approached from two perspectives: as an overarching logic of mobilization, which I have referred to as the politics of care, and as interactions among members of a social movement organization, which I have coined care work. 
The first contribution of care is to provide an explanation as to why some people contribute their private resources to creating an organization even if they do not expect to benefit directly from achieving its goals. As a logic of mobilization, care maps the origins of solidarity activism. Conscience entrepreneurs mobilize motivated by the empathy to the grievance of another group, taking responsibility to address their needs through collective action. The second contribution of this paper is an analysis of how organizations foster solidarity among their members. Before being able to address their grievances through contentious collective action, those oppressed must be emotionally prepared, develop identities that fit with their new roles as activists, and have enough time and knowledge to contribute to the activities of the organization. When these needs are not covered, individuals facing the same grievance may not develop solidarity with each other, despite sharing common interests. However, activists may create solidarity through care work. Organizational members generate emotions and identities that encourage participation in the movement. They also facilitate involvement by helping each other to find time for activism, as well as training each other to better contribute to the movement.

Although this paper has approached care with the aim of modeling social movement mobilization that originates from empathic solidarity, care has the potential to go beyond this condition. Empathy is also needed for self-interested cooperation, as self-interested actors need to understand each other's situation to perceive their common interests and how they can improve them through collective action. More research in this direction will further unpack the complexities of solidarity and how it influences contentious collective action. 


\section{Bibliography}

Aguilar Fernández, S., \& Fernández Gibaja, A. (2010). El movimiento por la vivienda digna en España o el porqué del fracaso de una protesta con amplia base social. Revista Internacional de Sociología, 68(3), 679-704.

Blanchar, C. (2014, February 22). Sí, pudieron. El País. Retrieved from https://politica.elpais.com/politica/2014/02/21/actualidad/1393010178_488272.html

Campos Echeverría, J. L. (2008). La burbuja inmobiliaria española. Madrid: Marcial Pons.

Collins, R. (2004). Interaction ritual chains. Princeton, NJ: Princeton University Press.

Consejo General del Poder Judicial. (2019). Datos sobre los efectos de la crisis en los órganos judiciales. Retrieved July 11, 2018, from http://www.poderjudicial.es/cgpj/es/Temas/EstadisticaJudicial/Estudios-e-Informes/Efecto-de-la-Crisis-en-los-organos-judiciales/Efecto-de-la-Crisisen-los-organos-judiciales

Della Porta, D. (Ed.). (2018). Solidarity Mobilizations in the 'Refugee Crisis.' Basingstoke, Hampshire: Palgrave Macmillan.

Della Porta, D., \& Diani, M. (2006). Social Movements: An Introduction. Malden, MA: Blackwell Publishing.

Di Feliciantonio, C. (2017). Social Movements and Alternative Housing Models: Practicing the "Politics of Possibilities" in Spain. Housing, Theory and Society, 34(1), 38-56.

Diani, M., \& McAdam, D. (Eds.). (2003). Social Movements and Networks: Relational Approaches to Collective Action. Oxford: Oxford University Press.

Durkheim, É. (1987 [1897]). Suicide: A Study in Sociology. New York, NY: Free Press.

Engster, D., \& Hamington, M. (Eds.). (2015). Care Ethics and Political Theory. Oxford University Press.

Evans, S. M., \& Boyte, H. C. (1986). Free spaces: The sources of democratic change in America. Chicago: University of Chicago Press.

Fireman, B., \& Gamson, W. A. (1979). Utilitarian logic in the resource mobilization perspective. In M. Zald \& J. D. McCarthy (Eds.), The dynamics of social movements: Resource mobilization, social control, and tactics (pp. 8-44). Cambridge, MA: Winthrop Publishers.

Flesher Fominaya, C. (2015). Redefining the Crisis/Redefining Democracy: Mobilising for the Right to Housing in Spain's PAH Movement. South European Society and Politics, 20(4), 465-485.

García-Lamarca, M. (2017a). Creating political subjects: Collective knowledge and action to enact housing rights in Spain. Community Development Journal, 52(3), 421-435.

García-Lamarca, M. (2017b). From Occupying Plazas to Recuperating Housing: Insurgent Practices in Spain. International Journal of Urban and Regional Research, 41(1), 37-53.

Gecas, V. (1982). The Self-Concept. Annual Review of Sociology, 8(1), 1-33.

Gecas, V. (1986). The Motivational significance of Self-Concept for Socialization Theory. In E. Lawler (Ed.), Advances in Group Processes (pp. 131-156). Greenwich: JAI Press.

Gecas, V. (1991). The Self-Concept as a Basis for a Theory of Motivation. In J. A. Howard \& P. L. Callero (Eds.), The Self-society dynamic: Cognition, emotion, and action. Cambridge: Cambridge University Press.

Gecas, V. (2000). Value Identities, Self-Motives, and Social Movements. In S. Stryker, T. J. Owens, \& R. W. White (Eds.), Self, Identity, and Social Movements (pp. 93-109). Minneapolis: University of Minnesota Press.

Gilligan, C. (1982). In a Different Voice. Cambridge, MA: Harvard University Press.

Goodwin, J., \& Pfaff, S. (2003). Emotion Work in High-Risk Social Movements: Managing Fear in the U.S. and East German Civil Rights Movements. In J. Goodwin \& J. M. Jasper (Eds.), Rethinking Social Movements: Structure, Meaning, and Emotion (pp. 282-302). Lanham, MD: Rowman \& Littlefield Publishers.

Gould, D. B. (2009). Moving Politics: Emotion and ACT UP's Fight against AIDS. Chicago, IL: University of Chicago Press. 
Groenhout, R. E. (2004). Connected Lives: Human Nature and an Ethics of Care. Lanham, MD: Rowman $\&$ Littlefield.

Hechter, M. (1987). Principles of group solidarity. Berkeley, CA: University of California Press.

Held, V. (2006). The ethics of care: Personal, political, and global. Oxford: Oxford University Press.

Hunt, S. A., \& Benford, R. D. (2004). Collective identity, solidarity, and commitment. In D. A. Snow, S. A. Soule, \& H. Kriesi (Eds.), The Blackwell companion to social movements (pp. 433-457). Malden, MA: Blackwell Pub.

Inglehart, R. (1977). The Silent Revolution: Changing Values and Political Styles Among Western Publics. Princeton University Press.

Jasper, J. M., \& Poulsen, J. D. (1995). Recruiting Strangers and Friends: Moral Shocks and Social Networks in Animal Rights and Anti-Nuclear Protests. Social Problems, 42(4), 493-512.

Jenkins, J. C. (1983). Resource Mobilization Theory and the Study of Social Movements. Annual Review of Sociology, 9(1), 527-553.

Klandermans, B., Roefs, M., \& Olivier, J. (2001). Grievance Formation in a Country in Transition: South Africa, 1994-1998. Social Psychology Quarterly, 64(1), 41-54.

Klandermans, B., van der Toorn, J., \& van Stekelenburg, J. (2008). Embeddedness and Identity: How Immigrants Turn Grievances into Action. American Sociological Review, 73(6), 992-1012.

Kriesi, H., Koopmans, R., Duyvendak, J. W., \& Giugni, M. G. (1995). New social movements in Western Europe: A comparative analysis. Minneapolis: University of Minnesota Press.

Link, B. G. (1987). Understanding Labeling Effects in the Area of Mental Disorders: An Assessment of the Effects of Expectations of Rejection. American Sociological Review, 52(1), 96-112.

Martinez, M. A. (2018). Bitter wins or a long-distance race? Social and political outcomes of the Spanish housing movement. Housing Studies, 1-24.

McAdam, D. (1986). Recruitment to High-Risk Activism: The Case of Freedom Summer. American Journal of Sociology, 92(1), 64-90.

McAdam, D. (1999 [1982]). Political Process and the Development of Black Insurgency, 1930-1970. Chicago, IL: University of Chicago Press.

McCarthy, J. D., \& Zald, M. N. (1977). Resource Mobilization and Social Movements: A Partial Theory. American Journal of Sociology, 82(6), 1212-1241.

Melucci, A. (1996). Challenging codes: Collective action in the information age. Cambridge: Cambridge University Press.

Melucci, A., Keane, J., \& Mier, P. (1989). Nomads of the present: Social movements and individual needs in contemporary society. Philadelphia: Temple University Press.

Messner, M. A., Greenberg, M. A., \& Peretz, T. (2015). Some Men: Feminist Allies in the Movement to End Violence against Women. Oxford University Press.

Meyer, D. S. (2004). Protest and Political Opportunities. Annual Review of Sociology, 30(1), 125-145.

Mir García, J., França, J., Macías Caparrós, C., \& Veciana, P. (2013). Fundamentos de la Plataforma de Afectados por la Hipoteca: Activismo, Asesoramientos Colectivo y Desobediencia Civil no Violenta. Educación Social. Revista de Intervención Socioeducativa, 55, 52-61.

Munro, L. (2005). Strategies, Action Repertoires and DIY Activism in the Animal Rights Movement. Social Movement Studies, 4(1), 75-94.

Nepstad, S. E. (2004). Convictions of the Soul: Religion, Culture, and Agency in the Central America Solidarity Movement. Oxford University Press.

Nepstad, S. E. (2008). Religion and War Resistance in the Plowshares Movement. Cambridge University Press.

Neuhouser, K. (1995). "Worse than Men": Gendered Mobilization in an Urban Brazilian Squatter Settlement, 1971-91. Gender \& Society, 9(1), 38-59.

Noddings, N. (1986). Caring: A Relational Approach to Ethics and Moral Education. Los Angeles, CA: University of California Press.

Noddings, N. (2015). Care Ethics and "Caring” Organizations. In D. Engster \& M. Hamington (Eds.), Care Ethics and Political Theory. Oxford: Oxford University Press. 
Olson, M. (1965). The logic of collective action: Public goods and the theory of groups. Cambridge, MA: Harvard University Press.

Plataforma de Afectados por la Hipoteca. (2013, February 9). La ILP para la dación en pago recoge 1,402,854 firmas de apoyo. Retrieved May 23, 2018, from Plataforma de Afectados por la Hipoteca website: http://afectadosporlahipoteca.com/2013/02/09/la-ilp-para-la-dacion-en-pago-recoge-1402-854-firmas-de-apoyo/

Plataforma de Afectados por la Hipoteca. (2016). Plataforma de Afectados por la Hipoteca: De la Burbuja Inmobiliaria al Derecho a la Vivienda. Retrieved February 28, 2017, from Plataforma de Afectados por la Hipoteca (PAH) website: http://afectadosporlahipoteca.com/

Plataforma de Afectados por la Hipoteca. (2019). Stop Desahucios. Retrieved July 19, 2019, from Afectados por la Hipoteca website: https://afectadosporlahipoteca.com/category/propuestaspah/stop-desahucios/

Polletta, F. (1999). "Free Spaces" in Collective Action. Theory and Society, 28(1), 1-38.

Robinson, F. (2011). The ethics of care: A feminist approach to human security. Philadelphia, PA: Temple University Press.

Romanos, E. (2014). Evictions, Petitions and Escraches: Contentious Housing in Austerity Spain. Social Movement Studies, 13(2), 296-302.

Russo, C. (2018). Solidarity in Practice: Moral Protest and the US Security State. Cambridge University Press.

Simola, S. (2003). Ethics of Justice and Care in Corporate Crisis Management. Journal of Business Ethics, $46(4), 351-361$.

Stall, S., \& Stoecker, R. (1998). Community Organizing or Organizing Community?: Gender and the Crafts of Empowerment. Gender \& Society, 12(6), 729-756.

Taylor, V. (1996). Rock-a-by Baby: Feminism, Self-Help and Postpartum Depression. New York: Routledge.

Televisión Española. (2004). Debate sobre la Burbuja Inmobiliaria. Retrieved July 19, 2019, from https://www.youtube.com/watch?v=eF007olk-Fw

Tong, R. (1998). The Ethics of Care: A Feminist Virtue Ethics of Care for Healthcare Practitioners. The Journal of Medicine and Philosophy, 23(2), 131-152.

Tronto, J. C. (1993). Moral Boundaries: A Political Argument for an Ethic of Care. New York, NY: Routledge.

Tronto, J. C. (2013). Caring Democracy: Markets, Equality, and Justice. New York, NY: New York University Press.

van Stekelenburg, J., \& Klandermans, B. (2013). The social psychology of protest. Current Sociology, 61(5-6), 886-905.

Vásquez-Vera, H., Fernández, A., Novoa, A. M., Delgado, L., Barcala, J., Macías, C., ... Photovoice Working Group of Public Health Agency of Barcelona. (2019). Our lives in boxes: Perceived community mediators between housing insecurity and health using a PHOTOVOICE approach. International Journal for Equity in Health, 18(1), 52.

Vásquez-Vera, H., Rodríguez-Sanz, M., Palència, L., \& Borrell, C. (2016). Foreclosure and Health in Southern Europe: Results from the Platform for People Affected by Mortgages. Journal of Urban Health, 93(2), 312-330.

Vecchione, M., Schwartz, S. H., Caprara, G. V., Schoen, H., Cieciuch, J., Silvester, J., ... Alessandri, G. (2015). Personal values and political activism: A cross-national study. British Journal of Psychology, 106(1), 84-106.

\footnotetext{
${ }^{1}$ Plataforma de Afectados por la Hipoteca.

${ }^{2}$ All interview excerpts have been translated from Spanish by the author.
} 
3 This calculation includes the parties Amaiur, Bloque Nacionalista Galego, Chunta Aragonesista, Compromís, Esquerra Republicana de Catalunya, Eusko Alkartasuna, Izquierda Unida, and Nafarroa Bai.

${ }^{4}$ Activists for the right to housing have identified that the media has recorded at least 43 suicides related to evictions since 2010. The full list can be found at:

https://15mpedia.org/wiki/Lista_de_suicidios_relacionados_con_desahucios (accessed on 9 July 2019)

${ }^{5}$ The video of this eviction blockade can be found through this link:

https://www.youtube.com/watch?v=FwrPYc1Uzwg (accessed on 9 July 2019) 